\title{
DETERMINING KEY ECOLOGICAL INDICATORS FOR URBAN LAND CONSOLIDATION
}

\author{
Kuo-Liang LIN \\ Department of Civil and Ecological Engineering, I-Shou University, No. 1, Sec 1, Suecheng \\ Township, Ta-Shu County, Kaohsing, Taiwan \\ E-mail: kllin@isu.edu.tw; phone: 886-939-058408
}

Received 20 August 2009; accepted 14 April 2010

\begin{abstract}
Urban land consolidation, which reforms land parcels to remove fragmentation and produce ideal blocks, is an effective means of urban renewal. Successful urban land consolidation benefits city officials as well as the general public, in improved city image, increased land value, and more effective land use. However, urban land consolidation can be ecologically detrimental to the environment, while land consolidation has focused solely on development for human benefit. To remove the negative effects of urban land consolidation on the ecological system, this paper establishes a set of criteria for evaluating ecological impacts of an urban land consolidation plan. The current study first identifies key ecological indicators using a special group decision-making process called "habitual domain analysis" and then records individual weighting of each indicator by an analytical hierarchy process, thus developing an urban ecological evaluation model with four levels and twenty-three indicators.
\end{abstract}

KEYWORDS: Ecological evaluation; Biodiversity; Urban renewal; Urban land consolidation; Habitual domains

\section{INTRODUCTION}

Urban renewal is a land re-development process in areas of moderate to high-density urban land use. Urban renewal is typically very controversial, and involves destroying original blocks, relocating people and using eminent domain as a legal instrument to reclaim private property for city-initiated development projects.

In Taiwan, urban land consolidation is one of the major implementing approaches for urban renewal. By reforming land parcels to remove fragmentation and produce ideal blocks, urban land consolidation is beneficial to both city officials and the general public, in improving city image, increasing land value, and using land more effectively. Disregarding its economical benefits, as urban land consolidation being a first-destruct-then-recover process, it is intended to overhaul the entire parcel structure and so forth results in negative impacts to its original dwellers, human and other creatures alike. To prevent public complaints against the project, urban land consolidation promoters should have their plan undertake Environmental Impact Assessment (EIA) procedure, which ensures identifying and assessing the environmental consequences of the project before its authorization. The public can then give its opinion, and the authorization procedure considers all results before informing the public of the decision to resolve controversy. However, the EIA itself has become a source of controversy in Taiwan (Chuang, 2008). 
With no standardized process or principals to follow, the outcomes and conclusions of EIA reports typically contain prejudices that often cause further conflicts between opposite parties. Unfortunately, idealization always has to compromise with the great temptation of potential economic gains in the case of large urban land consolidation (Chiang, 2004). Without proper planning, large urban land consolidation can become detrimental to environment, especially in the ecological aspects, as the execution of land consolidation is solely for the sake of human benefits. Decades-old trees being eradicated and other green space being bulldozed for large development happen from time to time with little mercy. Therefore, to ensure important ecological issues being addressed in EIA, deriving standard indicators is important so that people with different opinions can easily monitor and examine the assessment execution and prevent extinction of some precious ecological-enrichment opportunity in the urban area.

Sponsored by Taiwan's National Science Council, our research team aims at producing appropriate indicators to potentially support EIA, specifically for urban land consolidation, by involving ecological considerations and integrating them with current practices. Past urban land consolidation projects, like many other urban renewal development, are conducted in a human-centered philosophy. City officials focus only on the opportunity of large-scale infrastructure renewal to boost city economy and whether the project is self- compensable, while land owners and other partitioners care only about the economy benefits of increased land value after consolidation. To raise ecological concerns for the development of urban land consolidation, this research establishes a set of criteria for evaluating overall impacts of an urban land consolidation plan, and attempts to transform urban land consolidation as an opportunity of ecological system revival in the city limit through the re-organized land scheme when the projects can be properly carried out with increased ecological considerations.

Viewing the outcome of urban land consolidation project as a composite ecological system of human and other habitats including animals and plants, this paper discusses indicators regarding not only the traditional biological preservation of wild species but also human welfares. Traditionally, ecological indicators are used to assess the condition of the environment, to provide an early warning signal of changes in the environment, or to diagnose the cause of an environmental problem (Dale and Beyeler, 2001). Numbers of difference species of plants or animals are often selected as ecological indicators for reflecting a variety of aspects of ecosystems, including biological, chemical and physical, and the main purpose of these indicators is for monitoring and management (Niemeijer, 2002). For example, a research team at Florida International University has identified a small set of systemwide "ecological indicators", which includes 11 animals and plants, and these indicators are used to assess the restoration efforts in Florida Everglades (Doren et al., 2009).

Aiming at a balanced ecosystem that integrates human society with the natural environment, the indicators discussed in this paper stems beyond the traditional ecological indicators and enters the sustainability scope. Our research team thus develops an ecological evaluation model suitable for current urban land consolidation development in Taiwan, and the model uses Key Ecological Indicators covering important ecological, human welfare and sustainable concerns. This model can be a useful tool for city officials or other project stakeholders when carrying out overall planning of urban renewal projects involving land consolidation. 


\section{CURRENT STATE OF “GREEN" INDICATORS}

In order to identify appropriate indicators for urban land consolidation covering ecological, human welfare and sustainable concerns, it is necessary to review some key "green" indicators in various scopes of development.

In the scope of business, the ISO 14000 is a standard for environmental management systems that is applicable to corporations, aiming at reducing the environmental footprint of a business and to decrease the pollution and waste a business produces (ISO, 2009). Among various series of the ISO 14000 family, the ISO 14031 gives guidance on the design and use of environmental performance evaluation, and on identification and selection of environmental performance indicators, for use by all organizations. The ISO 14031 suggests that the selected indicators be divided into 3 categories: operating performance indicators (OPI), management performance indicators (MPI), and environmental condition indicators (ECI). Firms need to collect data for each indicator on a regular basis. In the scope of building, U.S. Green Building Council's LEED ${ }^{\mathrm{TM}}$ Green Building Rating System is one of the most notable concepts. LEED (Leadership in Energy and Environmental Design), with evaluators the 5 categories of Sustainable Sites, Water Efficiency, Energy and Atmosphere, Materials and Resources, Indoor Environmental Quality, and Innovation Credits, is a comprehensive system of building rating and certification, also aiming at reducing the environmental footprint and increasing the well-being of building occupants (USGBC, 2009).

Facing global warming issues, many countries have been promoting and pursuing ecocity implementation. For each eco-city project, promoters should identify performance indicators to monitor the developing progress. Recently, Sino-Singapore Tianjin Eco-city Joint
Working Committee has worked out 26 Key Performance Indicators to guide the city of Tianjin's planning and development into a model city for sustainable development (Tianjinecocity, 2009). There are 22 quantitative and 4 qualitative KPIs. Quantitative KPIs are divided in 4 categories: (1) Good Natural Environment (Ambient Air Quality, Quality of water bodies within the Eco-city, Quality of Water from Taps, Noise Pollution Levels, Carbon Emission Per Unit GDP, Net Loss of Natural Wetlands), (2) Healthy Balance in the Man-made Environment (Proportion of Green Buildings, Native Vegetation Index, Per Capita Public Green Space), (3) Good Lifestyle Habits (Per Capita Daily Water Consumption, Per Capita Daily Domestic Waste Generation, Proportion of Green Trips, Overall Recycling Rate, Access to Free Recreational and Sports Amenities, Waste Treatment, BarrierFree Accessibility, Services Network Coverage, Proportion of Affordable Public Housing) and (4) Developing a Dynamic and Efficient Economy (Usage of Renewable Energy, Usage of Water from Non-Traditional Sources, Proportion of R\&D Scientists and Engineers in the Eco-city Workforce, Employment-Housing Equilibrium Index); while the four Qualitative KPIs are "Maintain a safe and healthy ecology through green consumption and lowcarbon operations", "Adopt innovative policies that will promote regional collaboration and improve the environment of the surrounding regions", "Give prominence to the river estuarine culture to preserve history and cultural heritage, and manifest its uniqueness", and "Complement the development of recycling industries and promote the orderly development of the surrounding regions". Like Tiangjin, many other cities have proposed their own strategies towards sustainability (Abolina and Zilans, 2002; Ambiente Italia Research Institute, 2003; Boston foundation and greater Boston's civil community, 2007; Tomalty et al., 
2007; Sustainable Calgary, 2004). However, a growing number of experts have recognized that the development is at the local scale, i.e. at the level of municipalities, cities or metropolitan regions, that the challenges are best expressed and that actors must be mobilized (Camagni, 2002).

A research conducted in University of Quebec analyzed 17 studies of the use of urban sustainable development indicators (SDI) in developed western countries. The analysis reveals a lack of consensus not only on the conceptual framework and the approach favored, but also on the selection and optimal number of indicators (Tanguay et al., 2009).

The above-mentioned indicators in various contexts in general cover the aspects of environmental quality, sustainability (water, air, and materials), energy consumption, as well as human well-being. However, green space ecological disciplines, such as urban green space area, corridors, and biodiversity, which is also a critical element for quality of life of human inhabitants and global sustainability, has not been fully described. In larger development projects, such as eco-city implementation or urban land consolidation, where complex interactions between human behaviors and bio-physical processes may happens, these green space ecological disciplines should play a more important role. A number of studies in Europe have investigated the importance of such ecological discipline covering mainly urban green quality. Works by (Andrén, 1997; Hanski, 1999; Niemelä, 2001) discussed the effects of green space fragmentation, connectivity and isolatedness. Landscape Ecology by Forman and Godron (1986) also provides useful materials regarding the evaluation of size and shape effects of green spaces to the eco system. Venn's work in 2001 devised a set of criteria which can be utilized to objectively evaluate and compare urban green areas (Framework-5, 2001), and the criteria are divided in 5 major topics: (1) fragmentation,
(2) urban green protection, (3) biodiversity, (4) air quality, and (5) Hydology.

\section{RESEARCH METHODOLOGY}

This research includes two steps: (1) Identify Key Ecological Indicators (KEI) for urban land consolidation and (2) Determine individual weighting of each KEI. To determine the relative weighting for different indicators, most researches use the Analytical Hierarchy Process (AHP) is usually use. As a multi-goals seeking approach, AHP is generally applied to decisions comprised of multiple criteria under a uncertain scenario. A simple and clear hierarchical factor structure, categorized on the basis of experts and decision-makers (Saaty, 1980) precisely presents a complicated system. Experts' and decision-makers' dedicated analysis of factor weighting by pair wise comparison delivers a prioritized factor structure allowing for the best decision.

Before using AHP for decision-making, a solid hierarchical structure of factors should first be established. Studies often use the Delphi method, a structured process for collecting and distilling knowledge from experts by means of a series of questionnaires interspersed with controlled opinion feedback, to build the hierarchy. However, when consulted on key factors, experts' bias easily affects their thinking (or Habitual Domains) to carry out a faultless conclusion. To alleviate individual bias effects, one can use a special group decision-making approach called Habitual Domains Analysis. The Analog/Association theory from Habitual Domains developed by Dr. Yu P.L, aiming at expanding Habitual Domains, has potential to overcome bias constraints and compensate for the limitations of other human decision making processes (Yu and Chiang, 2002). Combining a fuzzy logic approach, the Habitual Domains theory can become an effective tool to reinforce AHP. Therefore, this research employs AHP, with the complementary Habitual 
Domains theory, to determine key ecological evaluators for urban land consolidation.

\section{HABITUAL DOMAIN ANALYSIS}

Dr. Yu's Habitual Domains theory declares that Human habitual domains are comprised of four elements (Yu, 1990):

1. Potential domain $\left(P D_{t}\right)$. The collection of all thoughts, concepts, ideas, and actions that can be potentially activated by one person or by one organization at time $t$.

2. Actual domain $\left(A D_{t}\right)$. The collection of all thoughts, concepts, ideas, and actions, which actually catch the attention and mind at time $t$.

3. Activation Probability $\left(A P_{t}\right)$. This represents the probability that ideas, concepts and actions in the potential domain can actually activate.

4. Reachable domain $\left(R D_{t}\right)$. This is the collection of thoughts, concepts, ideas, actions and operators generated from the initial actual domain.

This research applies Habitual Domains concepts to stimulate new information by combining expert knowledge and past research efforts. Dr. Yu has focused his original theory primarily on how to utilize individual habitual domains to develop personal fulfillment. Many researchers have followed and applied the ideas for group decision-making, especially in identifying key factors in resolving certain problem (Chen, 2006; Fu, 2003; Yang, 2003; Chen et al., 2002; Tzeng et al., 1998; Yang, 1996). To determine key factors, researchers have to go through extensive literature surveys and find a standard attribute set, which represents the current state of knowledge. Then an expert panel gathers to brainstorm on the factors to form the Actual Domain of expert knowledge, without exposed to the standard attribute set. Next, the expert panel uses analog and/or association to distill key ideas from the Actual domain and the standard attribute set. Finally, a stimulation process allows expansion of the original knowledge domain and refines the key factor set. Since the entire study process is a long and iterative one, the dedication of the expert panel is mandatory for this Habitual Domains decision-making process to be successful. Normally, a limited number of experts with sufficient expertise and abundant creativity is most desirable, and the process can be conducted several times to produce continuous improvement on the factors by involving different expert panels. The detailed process to identify key ecological indicators for urban land consolidation is described as follows:

\section{Step 1. Establish standard attribute set}

This step summarizes all ecological indicators through an intensive literature survey and these indicators form the standard attribute set $Y$ (Herricks, 2004; Cywinski, 2001; Dramstad et al., 1996; Platt, 1994; and Gilbert, 1989).

$Y=\ulcorner$ Standard attribute set $\lrcorner$ (Union set of the indicators from literature survey)

$$
Y=\bigcup_{j=1}^{h} y_{j}
$$

Table 1 summarizes the derived standard attribute set (Y). This standard attribute set, representing Actual Domains of the body of knowledge in the field of BCS, provides a sufficient base of possible ecological evaluators for urban land consolidation. However, since these factors are determined through combining various sources, many of these attributes inter-relate with each other, and their suitability for urban land consolidation also remains uncertain.

\section{Step 2. Establish actual domain of interviewed experts}

Actual domain is established using an open questionnaire to consult experts' opinions in performance indicators for the service industry. Assuming there are $k$ experts, and then $n$ attributes are referred, these form the actual domain of all experts $\mathrm{AD}_{k}$. In this step, the expert panel for this study involves ten experts, including 
five professors in the area of civil and ecological engineering, three government researchers, and two government officials experienced in the ecological engineering tendering process. This small but knowledgeable panel represents the rare selection of specialties in both ecological engineering as well as urban planning, and should be able to deliver the pioneering ecological indicators for urban land consolidation.

$\mathrm{AD}_{k}$ : actual domain by $k^{\text {th }}$ expert $(k=1$, $2,3, \ldots, n ; n=10$ in this case )

$\mathrm{AD}$ : actual domain of all experts

$$
\mathrm{AD}=\left\{\left(x, u_{A D}(x)\right) \mid x \in X\right\}
$$

$$
\begin{aligned}
& X=\bigcup_{k=1}^{n} \mathrm{AD}_{k}=U\left\{\mathrm{AD}_{k} \mid k=1,2,3, \ldots, n\right\}= \\
& \left\{x_{1}, x_{2}, x_{3}, \ldots, x_{n}\right\}
\end{aligned}
$$

\section{Step 3. Calculate "degree of membership" of each attribute in $\mathrm{AD}_{k}$}

As $\mathrm{AD}_{k}$ derives from experts' fuzzy point of view, utilizing a fuzzy statistic is required to retrieve attributes with greater expert consensus, called the degree of membership. The $\alpha$-cut utilized in the research is 0.5 , since many past works using habitual domains have suggested that 0.5 as an appropriate magnitude, meaning $50 \%$ of expert consensus is required

Table 1. Standard attribute set $\left(\mathrm{AD}_{0}\right)$

\begin{tabular}{lll}
\hline Dimension & No. & Standard attribute set $\mathrm{AD}_{0}$ \\
\hline Green spaces & $\mathrm{a} 1.1$ & Total green space area \\
& $\mathrm{a} 1.2$ & Landscape continuity \\
& $\mathrm{a} 1.3$ & Distance between green spaces \\
Corridors & $\mathrm{a} 1.4$ & Green space shape \\
& $\mathrm{a} 2.1$ & Corridor continuity \\
Land use & $\mathrm{a} 2.2$ & Corridor width \\
& $\mathrm{a} 2.3$ & Space continuity \\
Landscape characteristics & $\mathrm{a} 3.1$ & Building coverage ratio \\
& $\mathrm{a} 3.2$ & Land use types \\
Landscape strategic mechanism & $\mathrm{a} 4.1$ & Vegetation localization \\
Biodiversity & $\mathrm{a} 4.2$ & Landscape uniqueness \\
& $\mathrm{a} 5.1$ & Distance from source \\
& $\mathrm{a} 5.2$ & Resistance \\
Environmental impacts & $\mathrm{a} 6.1$ & Vegetation structure \\
Energy use & $\mathrm{a} 6.2$ & Habitat diversity \\
& $\mathrm{a} 6.3$ & Vegetation diversity \\
& $\mathrm{a} 7.1$ & Air quality improvement \\
& $\mathrm{a} 7.2$ & Waste reduction \\
& 8.1 & Energy consumption \\
& $\mathrm{a} 8.2$ & Use of new energy \\
& $\mathrm{a} 9.1$ & Flood control \\
& $\mathrm{a} 9.2$ & Water quality protection \\
\hline
\end{tabular}


for each attribute to remain in the $\mathrm{AD}$ (Chen, 2006; Fu, 2003; Yang, 2003, Chen et al., 2002; Tzeng et al., 1998; Yang, 1996).

Probability of occurrence of A:

$\mathrm{P}(\mathrm{A})=$ No. of ${ }^{\prime} \omega \in \mathrm{A}^{*} \div n$, where $n$ is the total number of tests.

Thus, the degree of membership can be represented by relative frequency, that is

$\mu \mathrm{AD}\left(x_{i}\right)$ : number of experts identifying $x_{i}$ in $\mathrm{AD} \div$ total experts,

$\mu \mathrm{AD}\left(x_{i}\right)$ : Attribute $\mathrm{x}_{i}$ 's degree of membership in $\mathrm{AD}$.

According to the fuzzy set theory, AD can be represented as follows:

$$
\mathrm{AD}=\sum_{j=1}^{t} \frac{\mu \mathrm{AD}\left(x_{i}\right)}{x_{i}} .
$$

Use $\alpha$-cuts to determine $\mathrm{AD}^{*}$, that is, to retrieve a qualified attribute set with the degree of membership over $\alpha$ :

$$
\mathrm{AD}^{*}=\mathrm{AD}_{\alpha}=\left\{x \in X \mid \mu_{\mathrm{AD}}(x)>\alpha\right\} .
$$

$\mathrm{AD}^{*}$ represents the attributes with Activation Probability over percentage $\alpha$.

Table 2 shows the $\mathrm{AD}_{1}$ with the degree of membership over $\alpha(=0.5) \cdot \mathrm{AD}_{1}$ represents the set of attributes with a greater degree of importance proposed by interviewed experts.

\section{Step 4. Develop reachable domain by analogy and/or association}

To develop a reachable domain, this study compares each pair of xi in $\mathrm{AD}^{*}$, and standard attribute $y_{j}$. Expert opinions are consulted to decide if $x_{i}$ can be referred to $y_{j}$ with analogy and/or association. The current investigation develops a two-round evaluation including degree of membership $(\alpha)$ and degree of correlation $(\beta)$ for this Reachable Domain analysis and only considers those indicators in the Standard
Attribute Set with both a sufficient degree of membership $(\alpha)$ and a degree of correlation $(\beta)$ as a reachable domain from the experts. When an attribute in $Y$ (standard attribute set) is referable and can be correlated by attributes in $\mathrm{AD}_{1}$, it implies that the attribute in $\mathrm{AD}_{1}$ covers the scope of the attribute in $Y$. That is, referable attributes are the reachable domain of the experts. Fuzzy statistics again determines the degree of membership and the degree of correlation.

R: $y$ referred by $x$ with analogy and/or association $\lrcorner$

$$
\mathrm{R}=\{(x, y)<\mu \mathrm{R}(x, y) \mid(x, y) X \times Y\}
$$

$\left(x_{i}, y_{j}\right)$ : No. of experts refer and correlate $x_{i}$ to $y_{i} \div$ No. of experts

where: $x_{i}$ in $i=1,2,3, \ldots, t$ and $j=1,2$, $3, \ldots, h$

The domain $\left(\mathrm{RD}\left(x_{i}\right)\right)$ referable from $\mathrm{AD}_{1}$ is therefore defined as the following:

$$
\begin{aligned}
& \mathrm{RD}\left(x_{i}\right)=\left\{y_{i} \mid \alpha\left(x_{i}\right) \geq 0.5, \beta\left(x_{i}\right) \geq 0.5 ; y_{i} \in \mathrm{Y}\right\} \\
& \forall x_{i} \in \mathrm{AD}_{1}
\end{aligned}
$$

The union set of all $\mathrm{RD}\left(x_{i}\right)$ from $\mathrm{AD}^{*}$ forms the total referable domain $\mathrm{RD}\left(\mathrm{AD}^{*}\right)$.

$$
\mathrm{RD}\left(\mathrm{AD}_{1}\right)=U\left\{\mathrm{RD}\left(x_{i}\right) \mid x_{i} \in \mathrm{AD}_{1}\right\}
$$

This research utilizes the attribute set of Table 1, and actual domains of experts in Table 2 , and applies the formula (1) (4), using $\alpha=0.5, \beta=0.5$ as suggested in previous works to determine the reachable domains of the interviewed experts, as listed in Table 3. (Chen, 2006; Fu, 2003; Yang, 2003; Chen et al., 2002; Tzeng et al., 1998; Yang, 1996).

\section{Step 5. Expand expert habitual domains by stimulation}

Through analysis of experts' reachable domains, this work determines leading ecological indicators with explicit expert consensus. 
However, since each expert's decision-making can be limited by his own habitual domains, it is necessary to use some stimulation so that their habitual domains can expand to activate and generate new ideas. That is, the stimulation approach allows experts to think beyond their own habitual domains. While remaining attributes in $\mathrm{AD}^{*}$ and $Y$ without sufficient consensus are beyond experts' reachable domains, these attributes are ideal igniters to stimulate experts' thinking. As the final step of HD analysis, this work exposes experts to these remaining attributes, and asks them to choose a few to supplement the original chosen attributes derived in Step 4. The $\alpha$-cut of 0.5 is again required for these supplementary attributes to enter the key ecological indicator pool.

Table 2. Actual domains by interviewed experts $\left(\mathrm{AD}_{1}\right)$

\begin{tabular}{|c|c|c|c|}
\hline Dimension & No. & Actual domain $\left(\mathrm{AD}_{1}\right)$ & $\alpha$ \\
\hline \multirow[t]{2}{*}{ Green space } & A1.1 & Total green space area & 0.7 \\
\hline & $\mathrm{A} 1.2$ & Vegetation combination & 0.5 \\
\hline \multirow[t]{2}{*}{ Corridor } & A2.1 & Corridor connectivity & 0.5 \\
\hline & $\mathrm{A} 2.2$ & Green corridor width & 0.6 \\
\hline \multirow[t]{2}{*}{ Land use } & A3.1 & Carrying capacity & 0.7 \\
\hline & A 3.2 & Land suitability & 0.5 \\
\hline \multirow[t]{2}{*}{ Landscape characteristics } & A4.1 & Landscape aesthetics & 0.5 \\
\hline & A 4.2 & Facility convenience & 0.7 \\
\hline \multirow[t]{2}{*}{ Biodiversity } & A6.1 & Species diversity & 0.9 \\
\hline & A6.2 & Habitat diversity & 0.7 \\
\hline Environmental impacts & A7.1 & Waste reduction & 0.7 \\
\hline Energy use & A8.1 & Energy consumption & 0.7 \\
\hline \multirow[t]{2}{*}{ Water resource management } & A9.1 & Soil water content & 0.7 \\
\hline & A9.2 & Waste water treatment system & 0.5 \\
\hline
\end{tabular}

Table 3. Reachable domain analysis

\begin{tabular}{lllllll}
\hline No. & Actual domain $\left(\mathrm{AD}_{1}\right)$ & No. & $\mathrm{AD}_{0}$ & $\alpha$ & $\beta$ & Reachable domain \\
\hline A1.1 & Total green space area & $\mathrm{a} 1.2$ & Landscape continuity & 0.8 & 0.55 & Yes \\
& & $\mathrm{a} 1.3$ & Distance between green spaces & 0.8 & 0.525 & Yes \\
& & $\mathrm{a} 1.4$ & Green area shape & 0.8 & 0.375 & No \\
A1.2 & \multirow{2}{*}{ Vegetation combination } & $\mathrm{a} 1.2$ & Landscape continuity & 0.7 & 0.375 & No \\
& & $\mathrm{a} 1.3$ & Distance between green spaces & 0.7 & 0.3 & No \\
& & $\mathrm{a} 1.4$ & Green area shape & 0.4 & & No \\
A2.1 & \multirow{2}{*}{ Corridor connectivity } & $\mathrm{a} 2.2$ & Green corridor width & 1 & 0.4 & No \\
& & $\mathrm{a} 2.3$ & Space continuity & 0.9 & 0.5 & Yes \\
A2.2 & \multirow{2}{*}{ Green corridor width } & $\mathrm{a} 2.1$ & Corridor continuity & 0.9 & 0.375 & No \\
& & $\mathrm{a} 2.3$ & Space continuity & 0.8 & 0.425 & No \\
A3.1 & \multirow{2}{*}{ Carrying capacity } & $\mathrm{a} 3.1$ & Building coverage ratio & 0.7 & 0.425 & No \\
& & $\mathrm{a} 3.2$ & Land use types & 1 & 0.55 & Yes \\
& & & & & (Continued) \\
\hline
\end{tabular}




\begin{tabular}{lllllll}
\hline No. & Actual domain $\left(\mathrm{AD}_{1}\right)$ & No. & $\mathrm{AD}_{0}$ & $\alpha$ & $\beta$ & Reachable domain \\
\hline \multicolumn{2}{l}{ (Continued) } & & & & & \\
A3.2 & Land suitability & $\mathrm{a} 3.1$ & Building coverage ratio & 0.8 & 0.475 & No \\
& & $\mathrm{a} 3.2$ & Land use types & 1 & 0.7 & Yes \\
& & $\mathrm{a} 3.2$ & Land use types & 0.9 & 0.625 & Yes \\
A4.1 & Landscape aesthetics & $\mathrm{a} 4.1$ & Vegetation localization & 0.5 & 0.3 & No \\
& & $\mathrm{a} 4.2$ & Landscape uniqueness & 1 & 0.55 & Yes \\
A4.2 & Facility convenience & $\mathrm{a} 4.1$ & Building coverage ratio & 0.4 & & No \\
& & $\mathrm{a} 4.2$ & Landscape uniqueness & 0.7 & 0.425 & No \\
A5.1 & Species diversity & $\mathrm{a} 6.1$ & Vegetation structure & 0.9 & 0.625 & Yes \\
& & $\mathrm{a} 6.2$ & Habitat diversity & 1 & 0.75 & Yes \\
& & $\mathrm{a} 6.3$ & Vegetation diversity & 1 & 0.775 & Yes \\
A5.2 & Habitat diversity & $\mathrm{a} 6.1$ & Vegetation structure & 0.9 & 0.475 & No \\
& & $\mathrm{a} 6.2$ & Habitat diversity & 0.9 & 0.475 & No \\
& & $\mathrm{a} 6.3$ & Vegetation diversity & 0.9 & 0.45 & No \\
A6.1 & Waste reduction & $\mathrm{a} 7.1$ & Air quality improvement & 0.9 & 0.6 & Yes \\
A7.1 & Energy consumption & $\mathrm{a} 8.1$ & Use of new energy & 0.8 & 0.55 & Yes \\
A8.1 & Soil water content & $\mathrm{a} 9.1$ & Flood control & 0.8 & 0.5 & Yes \\
& & $\mathrm{a} 9.2$ & Water quality protection & 0.7 & 0.475 & No \\
A8.2 & Waste water treatment & $\mathrm{a} 9.1$ & Flood control & 0.9 & 0.725 & Yes \\
& system & $\mathrm{a} 9.2$ & Water quality protection & 0.9 & 0.6 & Yes \\
\hline
\end{tabular}

After the expansion, nine more attributes are chosen with sufficient expert consensus. Among them, three are from the Standard Attributes Set $\mathrm{AD}_{0}$ (Green Area Shape, Space Continuity, and Building Coverage Ratio) and five are from some expert's habitual domain AD*(Green Area Diversity, Natural/Urban Corridor Ratio, Strategic Point Setting, Solid Waste Reduction, and Permeable Pavement Ratio), but did not receive sufficient consensus at a earlier stage. Together with the fourteen indicators in the original Actual Domain by all experts, the Habitual Domain Analysis generates a total of twenty-three indicators, as listed in Table 4. This study successfully demonstrates how Habitual Domains Analysis can expand the existing expert knowledge base in a way not easily achievable by other group decision approaches.
Table 4. 23 Key ecological indicators after HD expansion

\begin{tabular}{lll}
\hline No. & Key ecological indicator & Origin \\
\hline 1 & Green space area & $\mathrm{AD}_{1}$ \\
2 & Vegetation combination & $\mathrm{AD}_{1}$ \\
3 & Green space shape & $\mathrm{AD}_{0}$ \\
4 & Green space diversity & $\mathrm{AD}^{*}$ \\
5 & Corridor continuity & $\mathrm{AD}_{1}$ \\
6 & Corridor width & $\mathrm{AD}_{1}$ \\
7 & Space continuity & $\mathrm{AD}_{0}$ \\
8 & Natural/Urban corridor ratio & $\mathrm{AD}^{*}$ \\
9 & Species diversity & $\mathrm{AD}_{1}$ \\
10 & Habitat diversity & $\mathrm{AD}_{1}$ \\
11 & Strategic point setting & $\mathrm{AD}^{*}$ \\
12 & Distance between green spaces & $\mathrm{AD}_{0}$ \\
13 & Landscape aesthetics & $\mathrm{AD}_{1}$ \\
14 & Facility convenience & $\mathrm{AD}_{1}$ \\
15 & Carrying capacity & $\mathrm{AD}_{1}$ \\
& & $(\mathrm{Conntinued}$ \\
\hline
\end{tabular}




\begin{tabular}{lll}
\hline No. & Key ecological indicator & Origin \\
\hline \multicolumn{2}{l}{ (Continued) } & \\
16 & Land suitability & $\mathrm{AD}_{1}$ \\
17 & Building coverage ratio & $\mathrm{AD}_{0}$ \\
18 & Solid waste reduction & $\mathrm{AD}^{*}$ \\
19 & Waste gas reduction & $\mathrm{AD}_{1}$ \\
20 & Energy consumption & $\mathrm{AD}_{1}$ \\
21 & Soil water content & $\mathrm{AD}_{1}$ \\
22 & Waste water treatment system & $\mathrm{AD}_{1}$ \\
23 & Permeable pavement ratio & $\mathrm{AD}^{*}$ \\
\hline
\end{tabular}

$\mathrm{AD}_{1}$ : Original experts' actual domain

$\mathrm{AD}_{0}$ : Added from standard attribute set

$\mathrm{AD}^{*}$ : Add from some expert's habitual domain

\section{ANALYTICAL HIERARCHY PROCESS}

After deriving Key Ecological Indicators through HD analysis, this research uses the Analytical Hierarchy Process (AHP) to determine individual weighting of each Key Ecological Indicator (KEI). The following describes the AHP procedure:

\section{Step 1. Setting up the hierarchy}

A hierarchy constructing the problem with several levels must first be structured. The research team in this study constructs each level with a maximum of four factors so that the comparison between factors in step 2 will not be too complicated. The hierarchy is derived as in Figure 1. The first level denotes the overall goal to determine KEI weighting and is divided into three major categories: Ecological Concern, Human Concern, and Sustainable Concern. The third level further breaks down the second level, which breaks Ecological Concern with four directories (Green Space, Corridors, Biodiversity, and Landscape Strategic Mechanism), Human Concern with two directories (Land Use, and Design Characteristics), and Sustainable Concern with three directories (Waste Reduction, Energy Use, and Water Resource Management). The fourth level includes the twenty-two indicators derived from HD analysis in the previous section.

\section{Step 2. Factors comparison in each level}

The next AHP step compares the factors in each hierarchy level with each other to determine the relative importance of each dimension in accomplishing the overall goal. A matrix with the factors listed at the top and on the left is prepared for the experts surveyed. Based on individually surveyed information and the resulting informed judgment of the decision-maker, the matrix is then filled in with numerical values denoting the importance of the factor on the left relative to the importance of the factor on the top. Twenty-five experts are involved in this research survey.

\section{Step 3. Establish priority vector}

In this step, the numbers from the matrix in step 2 are used to obtain an overall priority value for each factor (Eigenvector). To do this, the evaluator calculates the sum of the values in each row of the matrix and divides each of the results by the sum of the results for all the rows. This is called the eigenvector method.

\section{Step 4. Test consistency of the matrix}

Consistence Index (C.I.) and Consistence Ratio (C.R) are calculated to test if each expert's rating of factors is consistent.

C.I $=(\lambda \max -n) / n-1$, where $n$ is the matrix size. Judgment consistency can be checked by taking the consistency ratio (CR) of CI with the appropriate value of average random consistency. Generally, C.R $<0.1$ indicates sufficient consistency. IF CR exceeds 0.1 , expert judgment is reviewed and the expert is consulted to improve CR.

\section{Step 5. Test overall consistency of the hierarchy and determine relative weighting of each factor}

This study uses C.R.H. (Consistency Ratio of Hierarchy) to determine overall hierarchy consistency. Again, C.R.H $<0.1$ indicates sufficient consistency. If the overall consistency is acceptable, relative weighting of each individual factor can be calculated. 


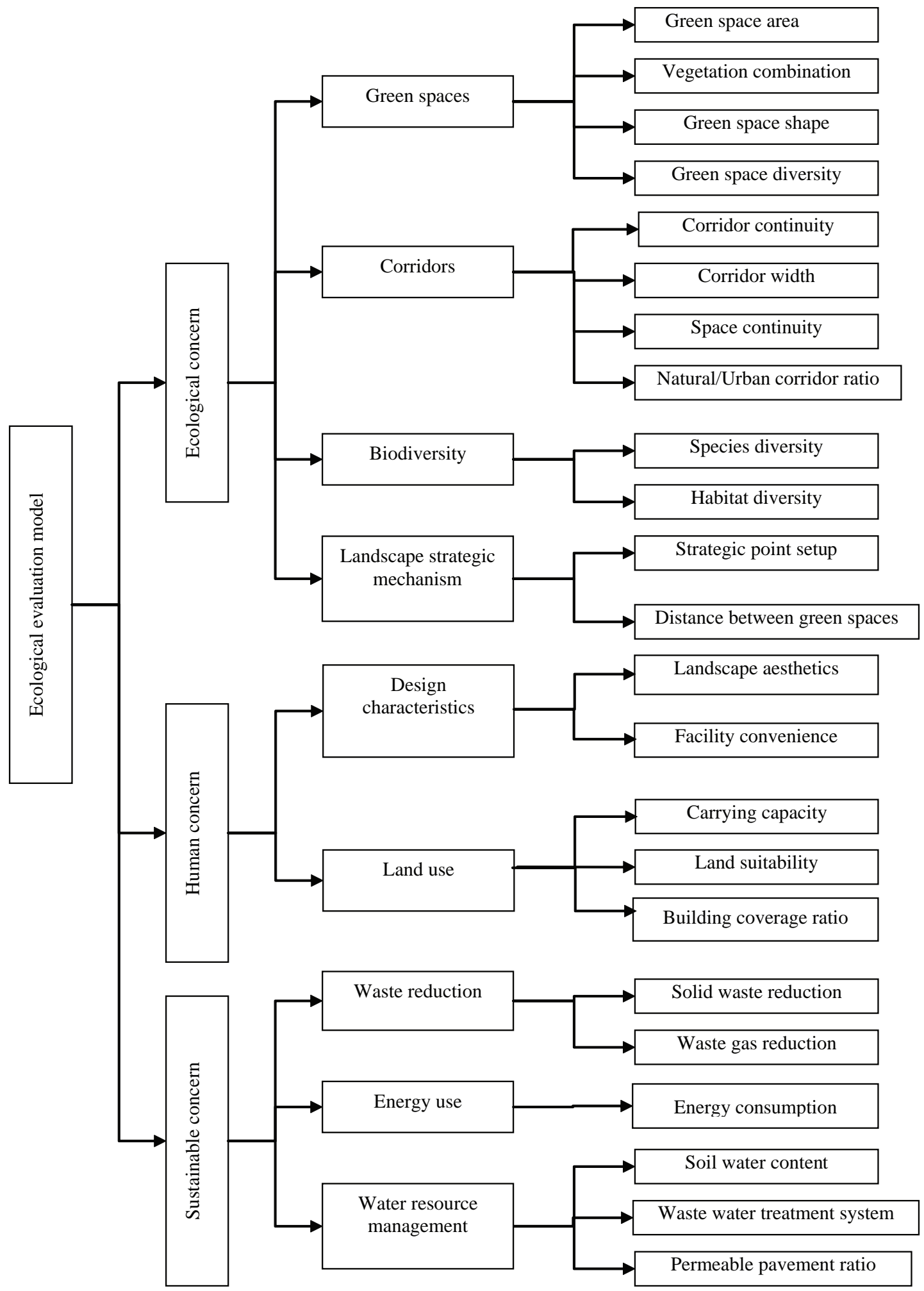

Figure 1. Ecological evaluation hierarchy for urban land consolidation 
After these five steps, the overall weighting in the second level and the third level can be finalized. Table V summarizes the overall weights of all indicators in all dimensions.

Based on experts' decision, "Ecological Concern" is the most important aspect, accounting for $46 \%$ of the total weighting, while "Sustainable Concern" is the runner-up at $42 \%$. "Human Concern" comes last at a mere $13 \%$, as Table 5 shows.

On second level dimensions, "Waste Reduction" (account for 17.22\%, "Biodiversity (17.02\%), Water Resource Management" (15.12\%), and "Green Spaces" (11.96\%) are deemed as the most important ones.

In Ecological Concern, "Habitat Diversity" (10.72\% overall) and "Species Diversity" (6.30\%) in Biodiversity dimension are considered the most important indicators. "Habitat Diversity" at the same time, is ranked No. 1 by experts among all twenty-three indicators. This explicitly indicates the importance of preserving animal habitats during any urban land consideration project. Destroying habitats for human's sake is considered disastrous from the ecological point of view.

Regarding Sustainable Concern, "Waste Gas Reduction" (10.33\%), and "Energy Consumption" (9.66\%) top all other indicators here, and they are also the top two and top three indicators among all, trailing only "Habitat Diversity" of Ecological Concern. Experts demonstrated strong willpower in this result to drive sustainable considerations into the urban land consolidation development, to realize the idea of creating an eco-city.

Regarding Human Concerns, experts chose "Facility Convenience" (3.36\%) as the most significant, but it is actually among the less important indicators (ranged only No. 12 of 23), while "Landscape Aesthetics" (1.58\%) is the least important indicator of all (ranked 23). This result shows experts' unambiguous intention to reduce the importance of human concern or human-centered preference during urban renewal. Experts believed these considerations were already the center of interest and out of proportion in many urban land consolidation projects, and thus they discouraged them to some extent.

Table 5. Key ecological indicators for urban land consolidation

\begin{tabular}{|c|c|c|c|}
\hline Concern & Dimension & No. & Indicator \\
\hline \multirow{12}{*}{$\begin{array}{l}\text { Ecological } \\
\text { concern }(46 \%)\end{array}$} & \multirow[t]{4}{*}{ Green spaces $(0.26,11.96 \%)$} & $\mathrm{S} 1.1$ & Green space area $(0.26,3.11 \%)$ \\
\hline & & $\mathrm{S} 1.2$ & Vegetation combination $(0.20,2.39 \%)$ \\
\hline & & $\mathrm{S} 1.3$ & Green space shape $(0.18,2.15 \%)$ \\
\hline & & $\mathrm{S} 1.4$ & Green space diversity $(0.35,4.19 \%)$ \\
\hline & \multirow[t]{4}{*}{ Corridors $(0.18,8.28 \%)$} & $\mathrm{S} 2.1$ & Corridor continuity $(0.30,2.48 \%)$ \\
\hline & & $\mathrm{S} 2.2$ & Corridor width $(0.21,1.74 \%)$ \\
\hline & & $\mathrm{S} 2.3$ & Space continuity $(0.27,2.24 \%)$ \\
\hline & & $\mathrm{S} 2.4$ & Natural/Urban corridor ratio $(0.23,1.90 \%)$ \\
\hline & \multirow[t]{2}{*}{ Biodiversity $(0.37,17.02 \%)$} & S3.1 & Species diversity $(0.37,6.30 \%)$ \\
\hline & & $\mathrm{S} 3.2$ & Habitat diversity $(0.63,10.72 \%)$ \\
\hline & \multirow{2}{*}{$\begin{array}{l}\text { Landscape strategic mechanism } \\
(0.19,8.74 \%)\end{array}$} & $\mathrm{S} 4.1$ & Strategic point setup $(0.61,5.33 \%)$ \\
\hline & & $\mathrm{S} 4.2$ & Distance between green spaces $(0.39,3.41 \%)$ \\
\hline \multirow{5}{*}{$\begin{array}{l}\text { Human concern } \\
(13 \%)\end{array}$} & \multirow{2}{*}{$\begin{array}{l}\text { Design characteristics } \\
(0.38,4.94 \%)\end{array}$} & S5.1 & Landscape aesthetics $(0.32,1.58 \%)$ \\
\hline & & $\mathrm{S} 5.2$ & Facility convenience $(0.68,3.36 \%)$ \\
\hline & \multirow[t]{3}{*}{ Land use $(0.62,8.06 \%)$} & $\mathrm{S} 6.1$ & Carrying capacity $(0.37,2.98 \%)$ \\
\hline & & S6.2 & Land suitability $(0.36,2.90 \%)$ \\
\hline & & S6.3 & Building coverage ratio $(0.27,2.18 \%)$ \\
\hline
\end{tabular}




\begin{tabular}{llll}
\hline Concern & Dimension & No. & Indicator \\
\hline (Continued) & & & \\
Sustainable & Waste reduction $(0.41,17.22 \%)$ & $\mathrm{S} 7.1$ & Solid waste reduction $(0.40,6.89 \%)$ \\
concern $(42 \%)$ & & $\mathrm{S} 7.2$ & Waste gas reduction $(0.60,10.33 \%)$ \\
& Energy use $(0.23,9.66 \%)$ & $\mathrm{S} 8.1$ & Energy consumption $(1.0,9.66 \%)$ \\
& Water resource management & $\mathrm{S} 9.1$ & Soil water content $(0.43,6.50 \%)$ \\
& $(0.36,15.22 \%)$ & $\mathrm{S} 9.2$ & Waste water treatment system $(0.28,4.23 \%)$ \\
& & $\mathrm{S} 9.3$ & Permeable pavement ratio $(0.29,4.38 \%)$ \\
\hline
\end{tabular}

\section{CONCLUSIONS}

This paper establishes a model for ecological evaluation of urban land consolidation. This model utilizes the habitual domains theory to extract Key Ecological Indicators (KEIs), and then applies AHP to determine the importance weighting of each KEI. Drawing on the habitual domains technique, this model identifies key indicators in three aspects with idea of bringing more ecological and sustainable concerns into urban land consolidation. AHP then provides sufficient expert knowledge in rating the possible impact of each indicator. While this paper proposes an innovative approach for a complete evaluation model in a more comprehensive, efficient and effective way, further empirical survey and testing using proper statistical methods is necessary to improve the reliability and validity of this model.

\section{REFERENCES}

Abolina, K. and Zilans, A. (2002) Evaluation of urban sustainability in specific sectors in Latvia, Environment, Development and Sustainability, 4(3), pp. 299-314. doi:10.1023/A:1021108324293

Ambiente Italia Research Institute (2003) European common indicators (ECI): towards a local sustainability profile, Final project report, Luxembourg: Office for official publications of the European Communities.

Andrén, H. (1997) Habitat fragmentation and changes in biodiversity, Ecological Bulletins, 46, pp. 171-181.
Boston foundation and greater Boston's civil community (2007) A summary of the Boston indicators report: 2004-2006, Boston foundation and greater Boston's civil community, 2007. Boston: The Boston Foundation.

Camagni, R. (2002) On the concept of territorial competitiveness: sound or misleading?, Urban Studies, 39(13), pp. 2395-2411. doi:10.1080/0042098022000027022

Chen, T.Y., Chang, H.L. and Tzeng, G.H. (2002) Using fuzzy measure and habitual domains to analyze the public attitude and apply to the gas taxi policy, European Journal of Operational Research, 137(1), pp. 145-161. doi:10.1016/S0377-2217(01)00137-0

Chen, W.L. (2006) Find the key success factors to manage aerobics clubs. Master's thesis, Taiwan: National Sun Yat-Sen University. (In Chinese)

Chiang, C.K. (2004) Urban politics-case study of the environmental impact assessment in Taipei. Master's thesis, Taiwan: National Taiwan University. (In Chinese)

Chuang, H.Y. (2008) The importance of conflict governance in the process of public construction: case study of Houli science park base. Master's thesis, Taiwan: National Chung-Hsin University. (In Chinese)

Cywinski, A. (2001) Current philosophy of sustainability in civil engineering, Journal of Professional Issues in Engineering Education and Practice-ASCE, 127(1), pp. 12-16. doi:10.1061/(ASCE)1052-3928(2001)127:1(12)

Dale, V.H. and Beyeler, S.C. (2001) Challenges in the development and use of ecological indicators, Ecological Indicators, 1(1), pp. 3-10. doi:10.1016/S1470-160X(01)00003-6

Doren, R.F., Trexler, J.C., Gottlieb, A.D. and Harwell, M.C. (2009) Ecological indicators for 
system-wide assessment of the greater everglades ecosystem restoration program, Ecological Indicators, 9(6), Supplement 1, pp. S2-S16. doi:10.1016/j.ecolind.2008.08.009

Dramstad, W.E., Olson, J.D. and Forman, R.T.T. (1996) Landscape ecology principles in landscape architecture and land-use planning, Washington, DC: Island Press.

Forman, R.T.T. and Godron, M. (1986) Landscape ecology, N.Y.: John Wiley \& Sons, Inc.

Framework-5 (2001) Development of URban GreEnspaces to improve the quality of life in cities and urban regions (URGE), Energy, environment and sustainable development, Fifth (EC) RTD Framework programme, The European Commission.

Fu, M.T. (2003) The KSF study of operating steel industry for Taiwanese merchant forward to Mainland China. Master's thesis, Taiwan: National Sun Yat-Sen University. (In Chinese)

Gilbert, O.L. (1989) The ecology of urban habitats, London: Chapman \& Hall.

Hanski, I. (1999) Habitat connectivity, habitat continuity, and metapopulations in dynamic landscapes, Oikos, 87(2), pp. 209-219. doi:10.2307/3546736

Herricks, E.E. (2004) Ecological engineering opportunities: multiple sector application and integration with a naturalization focus, International Conference on Eco-Technology, Taipei, Taiwan, 13-14 February 2004, pp. 1-11. (Available at: http://eem.pcc.gov.tw/eem/?q=node/145)

ISO (2009) ISO 14000 family. [Online] International Organization for Standardization. Available at: http://www.iso.org/iso/iso_catalogue/management_standards/iso_9000_iso_14000.htm [accessed 20 July 2008]

Niemeijer, D. (2002) Developing indicators for environmental policy: data-driven and theorydriven approaches examined by example, Environmental Science \& Policy, 5(2), pp. 91-103. doi:10.1016/S1462-9011(02)00026-6

Niemelä, J. (2001) Carabid beetles (Coleoptera: Carabidae) and habitat fragmentation: a review, European Journal of Entomology, 98(2), pp. 127-132.

Platt, R.H. (1994) The ecological city: introduction and overview. A world of cities. In: Platt, R.H.,
Rowntree, R.A. and Muick, P.C. (eds.), The Ecological city: preserving and restoring urban biodiversity, Amherst, MA.: University of Massachusetts Press, pp. 1-17.

Saaty, T.L. (1980) The analytic hierarchy process, NY: McGraw-Hill.

Sustainable Calgary (2004) State of our city report 2004, Sustainable Calgary, 2004. Calgary: City of Calgary.

Tanguay, G.A., Rajaonson, J., Lefebvre, J.F. and Lanoie, P. (2010) Measuring the sustainability of cities: an analysis of the use of local indicators, Ecological Indicators, 10(2), pp. 407-418. doi:10.1016/j.ecolind.2009.07.013

Tianjinecocity (2009) Key performance indicators. [Online] Available at: http://www.tianjinecocity.gov.sg/ [accessed 20 July 2008]

Tomalty, R., Alexander, D., Anielski, M., Wilson, J., Jozsa, A., Haider, M., Cartin-Artega, F., Casey, D. and Winfield, M. (2007) The Ontario urban sustainability report, 2007, Ottawa: The Pembina Institute.

Tzeng, G.H., Chen, T.Y. and Wang, J.C. (1998) A weight-assessing method with habitual domains, European Journal of Operational Research, 110(2), pp. 342-367. doi:10.1016/S0377-2217(97)00246-4

USGBC (2009) LEED 2009 for new construction and major renovations rating system. [Online] U.S. Green Building Council. Available at: http://www.usgbc.org/DisplayPage. aspx?CMSPageID=220 [accessed 20 July 2008]

Yang, S. (2003) The study of warships commercial maintenance system applied to commercial shipyards. Master's thesis, Taiwan: National Sun Yat-Sen University. (In Chinese)

Yang, Z.X. (1996) The study of advertiser selects the magazines media - the grey method and fuzzy decision method. Master's thesis, Taiwan: IShou University. (In Chinese)

Yu, P.L. (1990) Forming winning strategies: an integrated theory of habitual domains, New York: Springer-Verlag.

Yu, P.L. and Chiang, C.I. (2002) Decision making, habitual domains and information technology, International Journal of Information Technology and Decision Making, 1(1), pp. 5-26. doi:10.1142/S0219622002000063 


\section{SANTRAUKA}

\section{PAGRINDINIŲ EKOLOGINIŲ RODIKLIŲ NUSTATYMAS SUJUNGIANT MIESTŲ ŽEMĘ}

\section{Kuo-Liang LIN}

Miestu žemès sujungimas, kurio metu pertvarkomi žemės sklypai, pašalinamas susiskaldymas, pateikiami pavyzdiniai blokai, yra veiksmingos miestų atnaujinimo priemonès. Sèkmingas miestų žemès sujungimas naudingas miestų vadovams, taip pat plačiajai visuomenei, nes pagerina miesto i̇vaizdį, padidina žemès vertę ir veiksmingesni žemės naudojimą. Tačiau miesto žemès sujungimas gali būti ekologiškai kenksmingas aplinkai, nes tai atliekama tik žmonių naudai. Siekiant pašalinti neigiamą miestų žemès sujungimo poveiki ekologinei sistemai, šiame straipsnyje nustatomi tam tikri kriterijai, kuriais vadovaujantis vertinamas ekologinis miestų žemès sujungimo poveikis. Dabartinis tyrimas pirmiausia nustato pagrindinius ekologinius rodiklius, taikant specialu grupés sprendimų prièmimo metoda, vadinama iprastos aplinkos analize. Tada, atsižvelgiant $i$ analitini hierarchijos procesa, pagal svarbą nurodomi atskiri rodikliai ir sudaromas keturių lygiu ir dvidešimt triju rodiklių miesto ekologinis ịvertinimas. 